\title{
MECHANISM OF ACTIVATION OF GLUCOCEREBROSIDASE BY CO- $\beta$-GLUCOSIDASE (GLUCOSIDASE ACTIVATOR PROTEIN)
}

\author{
SUSAN L. BERENT and NORMAN S. RADIN \\ Mental Health Research Institute (Department of Psychiatry) and Department of Biological \\ Chemistry, University of Michigan, Ann Arbor, MI 48109 (U.S.A.)
}

(Received December 30th, 1980)

Key words: Glucosidase activator protein; Phosphatidylserine; Coglucosidase; Glucocerebrosidase binding; Glucosyl ceramide glucohydrolase; (Bovine spleen)

\section{Summary}

The nature of the stimulatory action of the protein 'coglucosidase' on glucocerebrosidase was investigated with the use of highly purified cofactor from bovine spleen, radioactive glucosyl ceramide and methylumbelliferyl- $\beta$-glucoside. A complex between coglucosidase and either substrate could not be detected under equilibrium and non-equilibrium binding conditions. Complex formation between stimulating protein and the enzyme could be shown by the binding of the enzyme to an affinity column containing coglucosidase. This binding could be blocked by adding phosphatidylserine to the enzyme. The lipid also stimulated the enzyme. Additional evidence for binding of the enzyme to the two kinds of stimulators was the finding that they protected the enzyme against inactivation by $N$-ethylmaleimide and chloromercuriphenylsulfonate.

A role for lipids in the stimulatory action of coglucosidase was shown by extracting lipids from the enzyme; this resulted in a loss of basal enzyme activity and of sensitivity to activation by the protein. Adding back the lipids or phosphatidylserine increased the sensitivity of the delipidated enzyme to coglucosidase.

Using the crude, unextracted enzyme we could show that low concentrations of phosphatidylserine augmented the effectiveness of coglucosidase but high concentrations of the lipid blocked the effect of the protein.

It is proposed that lipids, particularly acidic ones, act on solubilized glucocerebrosidase to produce an enzyme conformation which allows binding and stimulation by coglucosidase. At higher lipid concentrations, the acidic lipids 
bind, in competition with coglucosidase, to the latter's binding site on the enzyme.

\section{Introduction}

Little is known about the mechanism of activation of lysosomal hydrolases by their low molecular weight activating proteins (for which we propose the name cohydrolase, in analogy with colipase). In the case of the well-studied sulfatase system [1], cosulfatase acts as a detergent to break down large substrate micelles into an activator-substrate complex. It is proposed that the complex binds to the water-soluble enzyme, which then acts on the lipoidal sulfate ester. However, binding of activator to enzyme has not been demonstrated. A similar mechanism may be involved in the hexosaminidase system, since complexes of ganglioside $\mathrm{GM}_{2}$ and cohexosaminidase have been found [2]. This role for the cohydrolases is consistent with the finding that these enzymes cannot act on substrates in micellar form unless detergent or activating proteins are present, but that they do not require either for hydrolysis of water-soluble phenolic derivatives, such as methylumbelliferyl glycosides. Furthermore, the cohydrolases do not stimulate the hydrolysis of the latter substrates.

Coglucosidases for glucosyl ceramide glucohydrolase (EC 3.2.1.45) have been found in the spleens of Gaucher patients $[3,4]$ and steers [5], and in rat liver 'tritosomes' [6]. This hydrolysis system is clearly different in that the enzyme activity toward both the natural lipid (glucocerebroside and the artificial water-soluble (MeUmb-glucoside) substrates is stimulated by the activator proteins. Ho [7] has proposed that the enzyme, isolated from tissues, requires the Gaucher activator to create an active conformation of the enzyme. The association of the two proteins requires acidic phospholipid when solubilized glucosidase is used [8]. Support for this model came from the demonstration [9] that the soluble enzyme, in the presence of phosphatidylserine, bound selectively to an affinity column containing bound coglucosidase. There is as yet no information as to whether this activator proteins binds to the substrate.

We report here on our attempts to detect binding of MeUmb-glucosidase and glucocerebroside to co- $\beta$-glucosidase from bovine spleen, present evidence that the splenic activator (like the Gaucher co- $\beta$-glucosidase) also interacts with the enzyme, and show that the interaction is influenced by acidic lipids.

\section{Materials and Methods}

Coglucosidase and glucocerebrosidase were prepared from bovine spleen [5]. $\left[6{ }^{3} \mathrm{H}\right]$ Glucosyl ceramide, $85000 \mathrm{dpm} / \mathrm{nmol}$, was prepared from Gaucher spleen glucocerebroside [10]. $p$-Chloromercuriphenylsulfonic acid and $N$-ethylmaleimide were obtained from Sigma Chemical. Sepharose 4B activated by cyanogen bromide was a Pharmacia product. The other materials used have been described before [5].

Glucosidase assay. The standard incubations were done with $2 \mathrm{mM} \mathrm{MeUmb}-$ glucoside in $0.2 \mathrm{ml}$ of 'assay buffer' (50 mM sodium acetate, $\mathrm{pH} 4.5 / 0.05 \%$ Triton X-100). After $30 \mathrm{~min}$ at $37^{\circ} \mathrm{C}$, the liberated phenol was determined 
fluorimetrically after adding $1 \mathrm{ml}$ of $0.17 \mathrm{M}$ glycine carbonate, $\mathrm{pH} 10$ (365 $\mathrm{nm} / 450 \mathrm{~nm}$ ).

1 enzyme unit is defined as the amount of enzyme which yields $1 \mathrm{nmol}$ of methylumbelliferone per $\mathrm{h}$ when assayed in the standard procedure together with $0.1 \mathrm{mg} / \mathrm{ml}$ phosphatidylserine. Under this condition, the specific activity of a typical enzyme preparation was about 0.23 units per $\mu \mathrm{g}$ protein.

Coglucosidase assay. Enough glucosidase was used in the standard assay procedure to hydrolyze $1 \mathrm{nmol}$ of MeUmb-glucoside per $\mathrm{h}$ in the absence of acidic lipid. 1 unit of activator protein produced $150 \%$ of the basal activity [5].

Affinity column. Coglucosidase $(0.2 \mathrm{mg})$ and $0.1 \mathrm{~g}$ of activated Sepharose were coupled by the Pharmacia procedure, based on the method of Axén et al. [11], and excess reactive groups were blocked by reaction with ethanolamine. The packing, in a $3.8 \times 15 \mathrm{~mm}$ column, was washed with assay buffer contain-

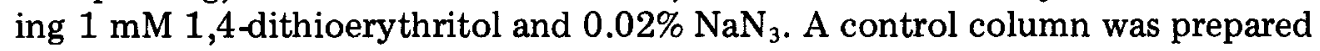
similarly but with omission of activator protein.

Electrophoresis. Two buffer systems were used. One was the discontinuous one of Williams and Reisfeld [12] with a stacking gel and a $7 \mathrm{~cm}$ main gel made from $5 \%$ acrylamide. The gels were run at $4 \mathrm{~mA} / \mathrm{gel}$ at room temperature with bromphenol blue tracking dye in a control gel.

The other electrophoretic method used produced steady-state binding conditions. Gels $(9 \mathrm{~cm})$ were made from $5 \%$ acrylamide containing $50 \mathrm{mM}$ sodium acetate, $\mathrm{pH} 5 / 0.05 \%$ Triton $/ 5 \mu \mathrm{M}\left[{ }^{3} \mathrm{H}\right]$ glucocerebrosidase. The reservoirs were filled with the same buffer without the labeled lipid and the gels were run at $6 \mathrm{~mA} /$ gel until the same endpoint as above.

The gels from the various runs were frozen and cut into $1.1 \mathrm{~mm}$ sections with a Bio-Rad gel slicer. The ${ }^{3} \mathrm{H}$ distribution was measured in adjacent pairs of slices by drying them in a paper combustion cone and oxidizing them with a Packard Oxidizer. Pairs of slices from other gels were extracted for $1 \mathrm{~h}$ at $37^{\circ} \mathrm{C}$ with $0.4 \mathrm{ml}$ of $5 \mathrm{mM}$ sodium phosphate, $\mathrm{pH} 7$, containing $0.1 \%$ Triton, to allow determination of their co- $\beta$-glucosidase activities.

Protein determination. The modification by Peterson [13] of the method of Lowry et al. [14] was used with bovine serum albumin as standard.

\section{Results}

Substrate-coglucosidase interaction. Binding of MeUmb-glucoside to co- $\beta$ glucosidase could not be demonstrated by gel permeation chromatography of $50 \mu \mathrm{g}$ co- $\beta$-glucosidase (about $10 \mathrm{nmol}$ ) and/or $200 \mathrm{nmol}$ of MeUmb-glucoside which had been incubated at $37^{\circ} \mathrm{C}$ for $30 \mathrm{~min}$ in $0.1 \mathrm{ml}$ of assay buffer. The sample permeated through a $0.8 \times 32 \mathrm{~cm}$ column of Sephadex G-75 equilibrated and eluted at $30 \mathrm{ml} / \mathrm{h}$ with the assay buffer held at $37^{\circ} \mathrm{C}$. Half of each $1 \mathrm{ml}$ column fraction was assayed for MeUmb-glucoside content by heating at $100^{\circ} \mathrm{C}$ for $90 \mathrm{~min}$ with $0.1 \mathrm{ml}$ of $6 \mathrm{M} \mathrm{HCl}$. The fluorescence of the liberated methylumbelliferone was measured after adding $0.1 \mathrm{ml}$ of $6.25 \mathrm{M}$ sodium glycinate buffer ( $\mathrm{pH} 10)$. This revealed a single peak near the total column volume containing all the MeUmb-glucoside in the original sample. The elution volume and amount were not affected by the preincubation with co- $\beta$-glucosidase, 
which eluted at the void volume. No MeUmb-glucoside was seen in the co- $\beta$ glucosidase peak.

The sensitivity of the assay for MeUmb-glucoside is such that less than 0.001 mol per mol of co- $\beta$-glucosidase could have been detected in the activator peak.

No binding of MeUmb-glucoside to co- $\beta$-glucosidase was found under equilibrium conditions in which $80 \mu \mathrm{M}$ co- $\beta$-glucosidase $(400 \mu \mathrm{g}$ in $1 \mathrm{ml}$ of assay buffer) was dialyzed at $37^{\circ} \mathrm{C}$ against assay buffer containing $80 \mu \mathrm{M}$ MeUmbglucoside. After $24 \mathrm{~h}$ the concentration of MeUmb-glucoside was found to be the same inside and outside the dialysis bag.

The discontinuous electrophoretic method was used to investigate binding of glucocerebroside to co- $\beta$-glucosidase. Labeled glucocerebroside $(2.5 \mathrm{nmol})$ and Triton $(50 \mu \mathrm{g})$ solutions were dried under $\mathrm{N}_{2}$, taken up in $0.1 \mathrm{ml}$ of $50 \mathrm{mM}$ sodium acetate, $\mathrm{pH} 5$, containing $50 \mu \mathrm{g}$ of co- $\beta$-glucosidase, and incubated 15 $\min$ at $37^{\circ} \mathrm{C}$. Analysis of the gel after electrophoresis of this solution showed that less than 5 pmol of cerebroside migrated at the dye front with the co- $\beta$ glucosidase. Other workers, using the same electrophoresis buffer system, have demonstrated binding between cosulfatase and cerebroside sulfate [1] and between cohexosaminidase and glycolipid $\mathrm{GA}_{2}$ [2].

Binding of the lipid to the activator was also tested by electrophoresis under steady-state binding conditions with a buffer in which co- $\beta$-glucosidase is known to be effective. No peak of radioactivity was found with the co- $\beta$-glucosidase peak after electrophoresis of $50 \mu \mathrm{g}$ activator through a gel containing $\left[{ }^{3} \mathrm{H}\right]$ cerebroside (Fig. 1). The small ${ }^{3} \mathrm{H}$ peak near the top of the gel was seen also in gels run without added co- $\beta$-glucosidase.

A final test of binding of $\left[{ }^{3} \mathrm{H}\right]$ cerebroside to Sepharose-bound co- $\beta$-glucosidase was made by applying $10 \mathrm{nmol}$ of the lipid in $2 \mathrm{ml}$ of assay buffer con-
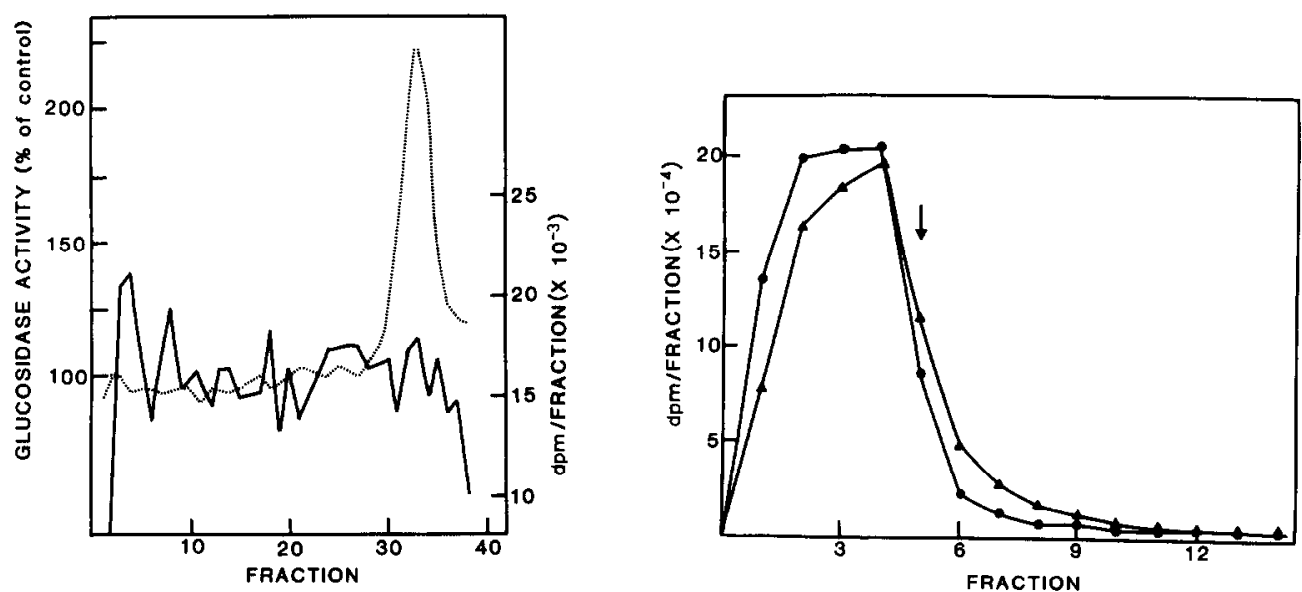

Fig. 1. Electrophoresis of coglucosidase through poly acrylamide gels containing $5 \mu \mathrm{M}\left[{ }^{3} \mathrm{H}\right]$ glucocerebroside at pH 5 . Gel slices were assayed for glucosidase stimulation (- . . . ) and radioactivity ( $\longrightarrow$ ).

Fig. 2. Chromatography of $\left[{ }^{3} \mathrm{H}\right]$ cerebroside with Sepharose-bound coglucosidase. The emulsified lipid was applied to either a control Sepharose column $(\bullet)$ or to a co- $\beta$-glucosidase-Sepharose column ( $\bullet$ ). The arrow indicates the end of sample application and start of buffer wash. The radioactivity in aliquots of the $0.5 \mathrm{ml}$ fractions was measured by liquid scintillation. 
taining $1 \mathrm{mM} 1,4$-dithioerythritol and $0.02 \%$ azide to the columns described in Materials and Methods. The sample, followed by the same buffer, was applied at room temperature at $10 \mathrm{ml} / \mathrm{h}$ (Fig. 2). Over $98 \%$ of the applied radioactivity was recovered in the effluent and the cerebroside peak was found to be only slightly retarded in the run with the co- $\beta$-glucosidase column, in comparison with the control column.

Interactions between coglucosidase and glucocerebrosidase. It is possible to make a Hill plot [15] by assuming that the basal enzyme activity is due to those enzyme molecules in our preparation which already have a single (endogenously-furnished) co- $\beta$-glucosidase molecule bound to them, and that the remaining glucosidase molecules possess no activator protein and hence are inactive. If all the binding sites are filled when the enzyme is maximally stimulated $(V)$, the increase in activity observed at any co- $\beta$-glucosidase concentration divided by the maximal increase in activity can be used in the Hill plot to represent the fraction of the enzyme molecules that are bound to co- $\beta$-glucosidase ( $Y$ in Hill's nomenclature). Using the data from the incubations with co- $\beta$ glucosidase concentrations of 21 to $1270 \mathrm{ng} / \mathrm{ml}$, we were able to obtain a straight line with a slope of 1.04 , a regression coefficient of 0.996 , and an intercept indicating a dissociation constant of $89 \mathrm{nM}$ co- $\beta$-glucosidase. The slope of 1.04 means that there is no cooperativity in the binding between the two proteins.

It has been shown that bovine co- $\beta$-glucosidase raises the $V$ and lowers the $K_{\mathrm{m}}$ for the splenic glucosidase when either MeUmb-glucoside or cerebroside is used as substrate [5]. This observation, together with the observed lack of co- $\beta$ glucosidase-substrate interaction, indicates formation of a co- $\beta$-glucosidaseenzyme complex. Kinetic analysis of the effect of co- $\beta$-glucosidase on MeUmbglucoside hydrolysis by a double reciprocal plot, using the increase in activity produced by co- $\beta$-glucosidase as the enzyme velocity, reveals a simple MichaelisMenten relationship, with an apparent $K_{\mathrm{m}}$ for co- $\beta$-glucosidase of $97 \mathrm{nM}$ (using an $M_{\mathrm{r}}$ of 4900 ).

Glucocerebrosidase is inactivated by the sulfhydryl reagent, $p$-chloromercuriphenylsulfonate $[16,17]$. Evidence for the interaction of co- $\beta$-glucosidase and phosphatidylserine with the enzyme was obtained by showing that these activators protected the enzyme from the thiol inhibitor. Pre-incubation of glucosidase in $50 \mu \mathrm{l}$ of assay buffer with or without co- $\beta$-glucosidase or phosphatidylserine for $15 \mathrm{~min}$ at $37^{\circ} \mathrm{C}$ was followed by addition of $50 \mu \mathrm{l}$ of buffer, with or without the mercurial. After $15 \mathrm{~min}$ of incubation, the residual enzyme activity was determined by adding MęUmb-glucoside and incubating in the usual way (Fig. $3 \Lambda$ ). The extent of inhibition was decreased by both activators and the efficiency of protection, in terms of molarity of activator needed, was much higher for the proteinaceous activator.

A parallel experiment, using $N$-ethylmaleimide instead of the mercurial, was identical except for the use of $\mathrm{pH} 5.5$ for the three incubations (Fig. 3B). We used 5.5 instead of 4.5 because $N$-ethylmaleimide reacts slowly below pH 6 . Results similar to those above were obtained.

Evidence for complex formation between co- $\beta$-glucosidase and the enzyme was sought by gel permeation of a mixture of the two in assay buffer contain- 

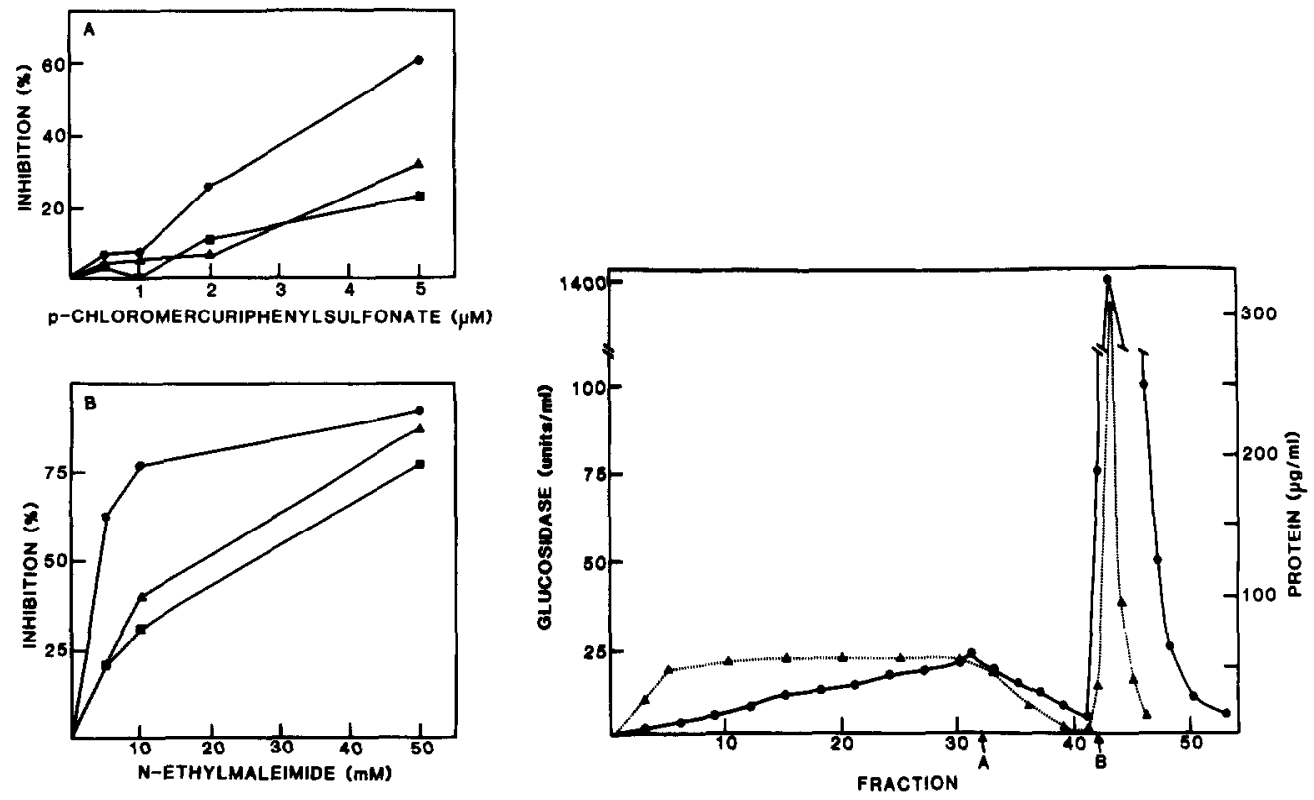

Fig. 3. Inhibition of glucosidase by sulfhydryl reagents. Glucosidase activity was measured after treatments of the enzyme with buffer or with $p$-chloromercuriphenylsulfonate (A) or with $N$-thylmaleimide (B) in the absence of added activator ( $\bullet$ ), in the presence of $10 \mu \mathrm{g} / \mathrm{ml}$ of co- $\beta$-glucosidase ( $A$ ), and in the presence of $200 \mu \mathrm{g} / \mathrm{ml}$ of phosphatidylserine $(\bullet)$ as described in the Results section. The control activities were compared with the appropriate experimental activities.

Fig. 4. Chromatography of glucosidase with Sepharose-bound coglucosidase. As the enzyme solution was added to the column, 6-ml fractions were collected; $1.5 \mathrm{ml}$ fractions were collected for the rest of the elution following point $A$. Starting buffer was added to the column at point $A$, high salt buffer at point $B$. Glucosidase concentration, $\bullet$; protein concentration, $\bullet$.

ing $1 \mathrm{mM} 1,4$-dithioerythritol and $0.02 \%$ azide through a Sepharose CL-6B column which was equilibrated and eluted with the same medium at $37^{\circ} \mathrm{C}$. Unfortunately, enzyme activity failed to appear in the effluent, with or without the presence of activator in the initial sample. Activity could not be detected even after assaying in the presence of phosphatidylserine or co- $\beta$-glucosidase or after recombining column fractions.

In a similar attempt, no enzyme activity could be detected after electrophoresis of a co- $\beta$-glucosidase/glucosidase mixture through a $5 \%$ polyacrylamide gel run with $50 \mathrm{mM}$ acetate, $\mathrm{pH} 5$, containing $0.05 \%$ Triton.

An interaction between the two proteins could be shown by passing a solution of the enzyme through a column containing bound co- $\beta$-glucosidase, prepared as described in Materials and Methods and operated at room temperature. Before application to the co- $\beta$-glucosidase column, the glucosidase preparation was diluted with 9 vol. of assay buffer containing $1 \mathrm{mM}$ 1,4-dithioerythritol and azide, then centrifuged $10 \mathrm{~min}$ at $10000 \times \mathrm{g}$. The supernatant contained $50-70 \%$ of the initial activity and about $15 \%$ of the protein, and showed the same sensitivity to co- $\beta$-glucosidase as before. (The buffer composition of the stock enzyme solution was altered by this procedure in order to produce conditions known to allow stimulation by co- $\beta$-glucosidase.) 
The solution was applied to the column at $10 \mathrm{ml} / \mathrm{h}$, followed by the same buffer. Bound enzyme was then eluted with $5 \mathrm{mM}$ sodium phosphate, $\mathrm{pH} 7$, containing $0.5 \mathrm{M} \mathrm{NaCl}$ and the Triton/azide/dithioerythritol supplement. In an experiment with 144 units of enzyme (211 $\mu \mathrm{g}$ protein) in $4 \mathrm{ml}$, all of the activity adhered to the packing and the eluting solution released $101 \%$ of the starting activity. The specific activity was increased 4.6-fold. In an experiment with 7000 units of enzyme (11.5 $\mathrm{mg}$ protein), applied at a concentration of 37 units $/ \mathrm{ml}$, only part of the enzyme was bound and the amount of enzyme activity eluting as the sample was applied slowly increased (Fig. 4). The 3800 units which eluted with the high salt buffer were 8-fold purified. This increase in purification with increased sample load reflects the binding by the column packing and replacement of more weakly bound proteins by glucosidase.

The maximal enzyme concentration in the effluent eluting during the sample application stage was lower than that in the applied solution (Fig. 4), showing that the column packing was not saturated. The control column, in a similar experiment, saturated rapidly, with only about 10 units of enzyme.

It was later found that the bound enzyme could be eluted with $0.5 \mathrm{M} \mathrm{NaCl}$ in pH 4.5 buffer as well as in pH 7 buffer.

Because Ho's [9] affinity column prepared from a co- $\beta$-glucosidase isolated from human Gaucher spleen required acidic phospholipids for the binding of a human $\beta$-glucosidase preparation, we applied 202 units of the bovine enzyme to our column in the same buffer as above, containing $0.1 \mathrm{mg} / \mathrm{ml}$ of phosphatidylserine (the concentration which produces maximal stimulation in our standard assay system). The column was washed with the same buffer mixture, then eluted with $0.5 \mathrm{M} \mathrm{NaCl}$ in the same buffer but without the lipid. The amount of enzyme eluting in the low-salt buffer was 152 units (compared to 14 when phosphatidylserine was omitted) and there was a corresponding decrease of $80 \%$ in the amount eluting with the high-salt buffer.

The binding characteristics of the enzyme were found to depend on the prior treatment of the enzyme. In one experiment, the glucosidase in the stock preparation was concentrated by adding ammonium sulfate, $350 \mathrm{mg} / \mathrm{ml}$, at $4^{\circ} \mathrm{C}$ and the resultant precipitate was extracted by sonication with $50 \mathrm{mM}$ acetate, $\mathrm{pH}$ 4.5, $0.3 \%$ Triton, and dithioerythritol/azide. The extract was dialyzed against the same buffer, centrifuged, and diluted to bring the solution to the composition of the buffer used in the column experiments. The preparation was not as sensitive to low co- $\beta$-glucosidase concentrations and did not bind to the column as well as before. For example, using an amount of enzyme activity that should have adhered completely to the column, only $43 \%$ bound. It seemed possible that the ammonium sulfate precipitation step had removed lipid from the enzyme, so enzyme was applied to the column in the presence of $100 \mu \mathrm{g} / \mathrm{ml}$ of phosphatidylserine. With this enzyme preparation, the lipid had no effect on the ability of glucosidase to bind to the activator column.

Conflicting results on the ability of acidic lipids to affect the stimulatory action of co- $\beta$-glucosidase have been reported $[4,8]$. Using our preparations, we found that co- $\beta$-glucosidase had a stimulatory effect at low phosphatidylserine concentrations and that the stimulation was enhanced by the lipid (Fig. 5). For example, $17 \mathrm{ng}$ of co- $\beta$-glucosidase caused an increase of $0.53 \mathrm{nmol} / \mathrm{h}$ in the absence of phosphatidylserine, and an increase of $0.93 \mathrm{nmol} / \mathrm{h}$ in the presence 
of $0.5 \mu \mathrm{g}$ of phosphatidylserine. However at a phosphatidylserine concentration that was maximally stimulatory, co- $\beta$-glucosidase produced no additional stimulation.

Since lipid was found to alter the effectiveness of co- $\beta$-glucosidase, we examined our enzyme preparation for lipid content by extraction with 4 vol. butanol/diisopropyl ether [18]. Thin-layer chromatography of the upper, organic layer with silica gel and a wide-range solvent showed the presence of many lipids, polar and nonpolar. The aqueous layer retained $23 \%$ of the original enzyme activity. Further extraction of this layer, with the more effective solvent, chloroform/methanol $2: 1$, showed that some phospholipids - much less than before - were still present.

The enzyme extracted with butanol/diisopropyl ether responded to phosphatidylserine but the stimulation was greater than that seen with the unextracted enzyme (8-fold vs. 4.5-fold) and the optimal concentration of the lipid was the same for both preparations. Other acidic phospholipids - phosphatidic acid, cardiolipin and phosphatidylinositol - also stimulated extracted glucosidase, but to not quite the same extent as phosphatidylserine. The delipidated enzyme was not as sensitive to co- $\beta$-glucosidase as the standard enzyme preparation. When an amount of either enzyme was used sufficient to yield a basal activity of $0.4 \mathrm{nmol} / \mathrm{h}, 28 \mathrm{ng}$ of co- $\beta$-glucosidase were required to raise the activity of the latter by $50 \%$ and $83 \mathrm{ng}$ were required to produce the same stimulation of the former. If $0.5 \mu \mathrm{g}$ of phosphatidylserine was included in the incubation with extracted enzyme, the requirement of $83 \mathrm{ng}$ was reduced to 36 (Fig. 6). Use of the total lipids extracted by butanol/diisopropyl ether from an equivalent amount of enzyme was even more effective in restoring the sensitivity to co- $\beta$-glucosidase: $13 \mathrm{ng}$ of co- $\beta$-glucosidase sufficed to produce $50 \%$ stimulation.
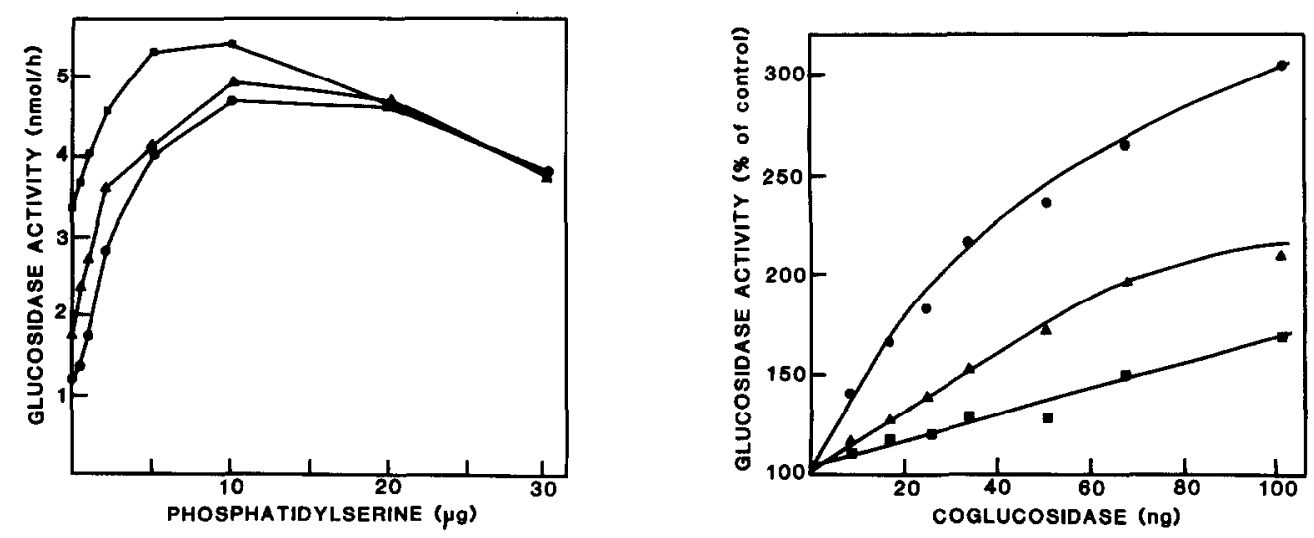

Fig. 5. Effect of coglucosidase on glucosidase activity in the presence of various amounts of phosphatidylserine. The activity was measured in the absence of the cofactor $(\bullet)$, or in the presence of $17 \mathrm{ng}$ coglucosidase ( $A$ ) or of $340 \mathrm{ng}$ coglucosidase ( $(\square)$.

Fig. 6. Effect of coglucosidase concentration on delipidated enzyme, The activity was measured without added lipid ( () , or with phosphatidylserine (A), or with lipids extracted from the original enzyme preparation (•). 


\section{Discussion}

There appears to be at least one $\beta$-glucosidase in tissues that does not act on glucosyl ceramide, but does act on MeUmb-glucoside. The enzyme that hydrolyzes the lipid also acts on MeUmb-glucoside. Spleen has been reported to contain primarily glucocerebrosidase $[19,20]$. Our previous study [5] has shown that there is a strikingly parallel subcellular distribution of the two activities in bovine spleen and that all of the activity toward MeUmb-glucoside is inactivated by conduritol B epoxide, an inhibitor of glucocerebrosidase [21]. While much of the literature on animal $\beta$-glucosidases is confusing, in part because of the use of many different assay conditions, it appears that the enzyme(s) inactive toward cerebroside occurs primarily in the soluble part of tissues. The enzyme used in this study was obtained from membranes. In view of these considerations, we believe that our enzyme is glucocerebrosidase and that the use of MeUmb-glucoside (as well as the lipid) in this study is appropriate.

The activator proteins for cerebroside sulfate sulfatase and ganglioside acetylgalactosaminidase do not stimulate hydrolysis of the water-soluble artificial substrates and evidently form complexes with the ceramide moieties of the natural substrates, although they presumably distinguish between the polar moieties. Our findings show that splenic co- $\beta$-glucosidase, on the other hand, stimulates the hydrolysis of both types of substrate yet does not form complexes with either under equilibrium or nonequilibrium conditions in which co- $\beta$-glucosidase is known to be effective. The former enzymes are much more readily solubilized than glucosidase and may, therefore, occur predominantly in the soluble portion of the lysosomes; this may explain their need for carrier proteins to extract the insoluble substrates from ingested membrane fragments and bring them into contact with the enzymes' active sites. In the case of glucocerebrosidase, however, which seems to be bound tightly to lysosomal membranes, the substrate may approach the enzyme by lateral diffusion after fusion of the lysosomal and ingested membranes. There is, therefore, no need for a carrier protein and co- $\beta$-glucosidase may play an entirely different role.

Several kinds of evidence from this and other studies point to binding between co- $\beta$-glucosidase and glucocerebrosidase as part of its function. Co- $\beta$ glucosidase lowers the $K_{\mathrm{m}}$ for the substrate and raises the $V[4,5]$, co- $\beta$-glucosidase and the enzyme show a Michaelis-Menten relationship, it protects the enzyme against inactivation by thiol reagents and by heat [22], and both Gaucher [9] and bovine co- $\beta$-glucosidase bind the enzyme when immobilized on a column packing. The ability of Gaucher co- $\beta$-glucosidase to stabilize normal placental glucocerebrosidase against the effect of low $\mathrm{pH}$ and to lower the optimum $\mathrm{pH}$ of the enzyme [23] is additional evidence for an interaction between the two proteins.

The effects of acidic lipids on co- $\beta$-glucosidase action can be explained by postulating three modes of interaction. One, at low lipid concentrations, is an effect on solubilized glucocerebrosidase which changes the conformation of the enzyme so that it can combine with and be stimulated by co- $\beta$-glucosidase. This enzyme form is probably similar to the one found in the original membranes in 
which it occurs. The second, at higher lipid concentrations, is a competitive binding to the site that normally binds co- $\beta$-glucosidase. At this site, the two stimulators produce an activated form(s) of the enzyme, although the lipid is much less efficient that co- $\beta$-glucosidase. At high lipid concentrations, the enzyme finds itself bound to a micellar form of the lipid and thus less active. An alternative hypothesis for the third effect is that the lipid micelles bind the substrate and reduce its availability to the enzyme.

Attempts at therapy of Gaucher's disease have been made by injecting highly purified, soluble glucocerebrosidase [24-26]. This preparation is not in its fully activated form, as shown by the stimulatory effect of taurocholate and of co- $\beta$-glucosidase [5]. Presumably the injected enzyme would be taken up by the patient's cells and activated by endogenous co- $\beta$-glucosidase or acidic lipids. While there is apparently ample co- $\beta$-glucosidase in the patient, it is possible that it is all bound to the defective cerebrosidase already present and is, therefore, unavailable for activation of the injected enzyme. Another possibility is that endogenous co- $\beta$-glucosidase is simply physically inaccessible, in a different compartment that does not take up the new enzyme. In view of the reports of the ineffectiveness of the therapeutic attempts, it would seem advisable to test the injection of enzyme already activated with lipids and co- $\beta$-glucosidase.

\section{Acknowledgements}

The authors are indebted to Janet Selmek for her tireless and dedicated assistance in the laboratory. This research was supported by a grant from the National Institutes of Health, NS-03192.

Note added in proof (Received April 28th, 1981)

A report has recently appeared [27] describing a purified protein isolated from spleens of Gaucher patients. This protein stimulated not only human glucocerebrosidase, but also galactocerebrosidase and sphingomyelinase. Ganglioside $\mathrm{GM}_{2}$ galactosidase was not affected. Dr. Wenger kindly tested our bovine protein and found the same stimulatory effects. Evidently a single protein is necessary for the activity of the three lysosomal enzymes which act on the least polar of the sphingolipids. Ceramidase may have to be added to this group.

\section{References}

1 Fischer, G. and Jatzkewitz, H. (1978) Blochim. Biophys. Acta 528, 69-76

2 Conzelmann, E. and Sandhoff, K. (1979) Hoppe-Seyler's Z. Phy siol. Chem. 360, 1837-1849

3 Ho, M.W., O'Brien, J.S., Radin, N.S. and Erickson, J.S. (1973) Biochem. J. 131, 173-176

4 Peters, S.P., Coyle, P., Coffee, C.J., Glew, R.H., Kuhlenschmidt, M.S., Rosenfeld, L. and Lee, Y.C. (1977) J. Biol. Chem. 252, 563-573

5 Berent, S.L. and Radin, N.S. (1981) Arch. Biochem, Biophys. 207, in the press

6 Mraz, W., Fischer, G. and Jatzkewitz, H. (1876) FEBS Lett. 67, 104-109

7 Ho, M.W. (1973) Biochem. J. 136, 721-729

8 Ho, M.W. and Light, N.D. (1973) Biochem. J. 136, 821-823

9 Ho, M.W. (1975) FEBS Lett. 53, 243-247

10 McMaster, M.C. and Radin, N.S. (1977) J. Labelled Comp. Radiopharm, 13, 353-357

11 Axén, R., Porath, J. and Ernback, S. (1967) Nature 214, 1302-1304

12 Williams, D.E. and Reisfeld, R.A. (1964) Ann. N.Y. Acad. Sci. 121, 373-381 
13 Peterson, G.L. (1977) Anal. Biochem. 83, 346-356

14 Lowry, O.H., Rosebrough, N.J., Farr, A.L. and Randall, R.J. (1951) J. Biol. Chem. 193, 265-275

15 Hill, A.V. (1913) Biochem. J. 7, 471-480

16 Hyun, J.C., Misra, R.S., Greenblatt, D. and Radin, N.S. (1975) Arch. Biochem. Biophys. 166, 382389

17 Kanfer, J.N., Stein, M. and Spielvogel, C. (1972) in Sphingolipids, Sphingolipidosis, and Allied Disorders (Volk, B.W. and Aronson, S.M., eds.), pp. 225-236, Plenum Press, New York

18 Cham, B.E. and Knowles, B.R. (1976) J. Lipid Res. 17, 176-181

19 Peters, S.P., Coyle, P. and Glew, R.H. (1976) Arch. Biochem. Biophys. 175, 569-582

20 Yaqoob. M. and Carroll, M. (1980) Biochem. J. 185, 541-543

21 Daniels, L.B., Glew, R.H., Radin, N.S. and Vunnam, R.R. (1980) Clin. Chim. Acta 106, 155-163

22 Pentchev, P.G., Brady, R.O., Blair, H.E., Britton, D.E. and Sorrell, S.H. (1978) Proc. Natl. Acad. Sci. U.S.A. 75, 3970-3973

23 Pentchev, P.G., Brady, R.O., Hibbert, S.R., Fal, A.E. and Shapiro, D. (1973) J. Biol. Chem. 248, 5256-5261

24 Brady, R.O., Barranger, J.A., Gal, A.E., Pentchev, P.G. and Furbish, F.S. (1980) in Enzyme Therapy in Genetic Diseases, Vol. 2 (Desnick, R.J., ed.), pp. 361-368, Alan R. Liss, New York

25 Beutlex, E., Dale, G.L. and Kuhl, W. in Enzyme Therapy in Genetic Diseases, Vol. 2 (Desnick, R.J., ed.), pp. 369-382, Alan R, Liss, New York

26 Gregoriadis, G., Neerunjun, D., Meade, T.W., Goolamali, S.K., Weereratne, H. and Bull, G. in Enzyme Therapy in Genetic Diseases, Vol. 2 (Desnick, R.J., ed.), pp. 383-392, Alan R. Liss, New York

27 Wenger, D.A., Sattler, M. and Roth, S. (1981) Trans. Am. Soc. Neurochem. 12, 210 